\title{
Why Do the Fetal Membranes Rupture Early after Fetoscopy? A Review
}

\author{
Benjamin J. Amberg ${ }^{a, b}$ Ryan J. Hodges ${ }^{a, b}$ Karyn A. Rodgers ${ }^{a, b}$ \\ Kelly J. Crossley ${ }^{a, b}$ Stuart B. Hooper ${ }^{a, b}$ Philip L.J. DeKoninck ${ }^{a, b}, c$ \\ aThe Department of Obstetrics and Gynaecology, School of Clinical Sciences, Monash University,

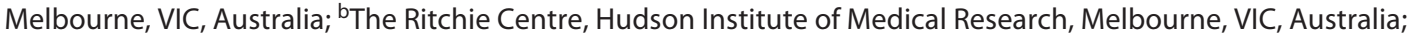 \\ 'Department of Obstetrics and Gynaecology, Erasmus MC, University Medical Center, Rotterdam, The Netherlands
}

\section{Keywords}

Amnion · Chorion · Fetoscopy · latrogenic preterm premature rupture of membranes - Matrix metalloprotease • Preclinical model

\section{Abstract}

latrogenic preterm premature rupture of the fetal membranes (iPPROM) remains the Achilles' heel of keyhole fetal surgery (fetoscopy) despite significant efforts in preclinical models to develop new therapies. This limited success is partially due to incomplete understanding why the fetal membranes rupture early after fetoscopy and notable differences in membrane physiology between humans and domestic species. In this review, we summarize aspects of fetoscopy that may contribute to iPPROM, the previous efforts to develop new therapies, and limitations of preclinical models commonly used in fetal membrane research.

(C) 2021 The Author(s)

Published by S. Karger AG, Basel

\section{karger@karger.com www.karger.com/fdt

\section{Introduction}

Keyhole fetal surgery (fetoscopy) is used to treat complicated monochorionic twin pregnancies or fetuses with congenital abnormalities $[1,2]$. These procedures are generally performed at mid-gestation using a camera and instruments inserted into the amniotic space through ports in the uterus and fetal membranes [3]. The ports can be positioned percutaneously or the uterus can be partially exteriorized and the ports inserted directly [4]. More complex fetoscopic procedures require gaseous distension of the amniotic cavity (amniotic insufflation) to improve visibility within the uterus and allow easier manipulation of surgical instruments [5]. While fetoscopy aims to improve postnatal outcomes, postoperative iatrogenic preterm premature rupture of the fetal membranes (iPPROM) remains its Achilles' heel. iPPROM complicates $\approx 30 \%$ of fetoscopic procedures, but rates can be as high as $85-100 \%$ following complex procedures using amniotic insufflation [510]. iPPROM increases the risk of lung hypoplasia due to prolonged oligohydramnios, chorioamnionitis, and preterm birth, all of which have significant implications

Correspondence to:

Philip L.J. DeKoninck, p.dekoninck@erasmusmc.nl 
Table 1. Potential mechanisms of iatrogenic PPROM and novel therapies

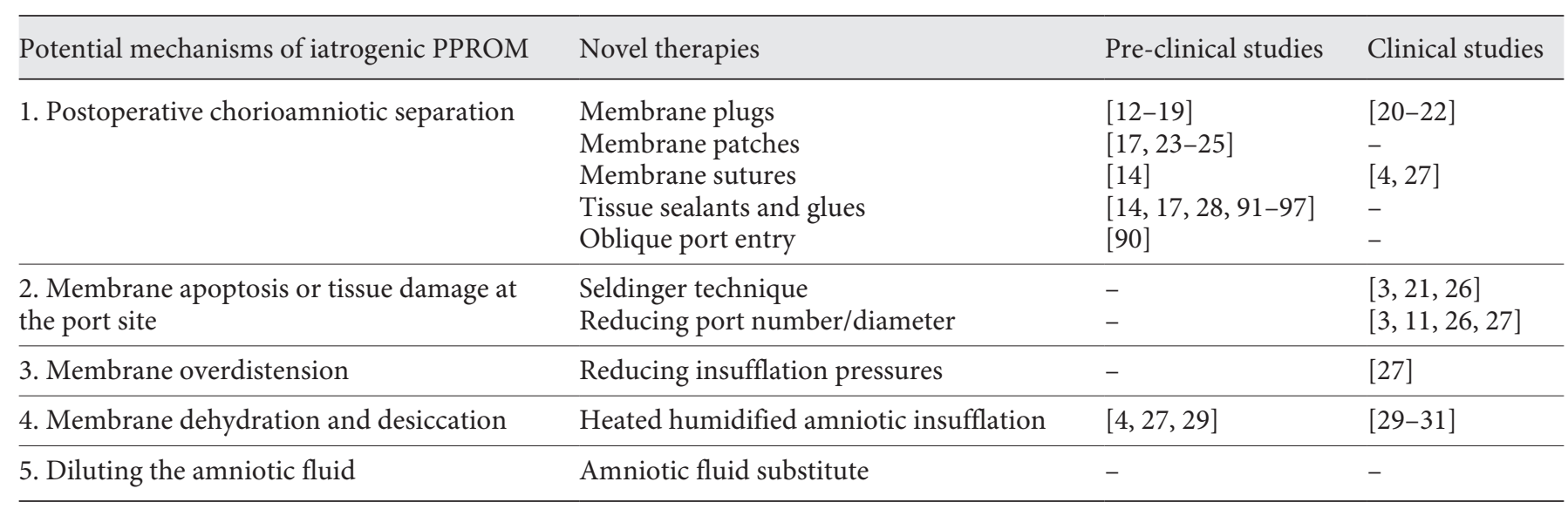

for the fetus and potentially offset the benefits of surgery [11]. Although perinatal outcomes are generally improving after fetoscopy, the risk of iPPROM means these procedures are only considered for the most severely affected fetuses, where the potential advantages of surgery outweigh the significant risks $[1,4,10]$.

Techniques to reduce iPPROM after fetoscopy have been investigated extensively in humans and preclinical models (summarized in Table 1) [6]. Efforts have mainly focused on minimizing membrane damage by reducing the number and diameter of fetoscopic ports and using plugs (gelatin or collagen), glues, patches, or sutures to seal the holes left in membranes after surgery [3, 11-28]. More recently, heated and humidified $\mathrm{CO}_{2}$ gas has been used for amniotic insufflation to prevent the fetal membranes dehydrating and becoming prone to rupture after surgery [4, 27, 29-31]. Although many of these techniques have been shown to protect the membranes from injury or prevent amniotic fluid leakage (amniorrhexis) in preclinical models, there is limited evidence to show they reduce iPPROM in humans [3, $11,26,32]$. This difficulty developing and translating strategies to reduce iPPROM is largely due to the limited understanding why the fetal membranes rupture early after fetoscopy. Herein, we summarize the potential mechanisms and preventions of iPPROM after fetoscopy. In addition, we provide an overview of preclinical models commonly used in fetal membrane research and describe their relevance to human fetal membrane physiology.

\section{Structure of the Human Fetal Membranes}

The fetal membranes surround the fetus during pregnancy and play a critical role in maintaining the pregnancy to term (shown in Fig. 1) [33]. The innermost membrane, the amnion, provides the majority of structural integrity [33]. The amnion is formed 10-14 days postfertilization when mesoderm cells migrate from between the layers of the bilaminar embryo to fuse with the ectoderm lining of the amniotic cavity [34]. The ectoderm gives rise to the cuboidal amniotic epithelium which lines the surface of the amnion facing the fetus and is held in place by a basement membrane composed of collagens (type I and III) and glycoproteins (laminin, nidogen, and fibronectin) [34-36]. The amniotic mesoderm forms a layer of compact type I and III collagen beneath the basement membrane that provides the amnion with its tensile strength $[33,35,36]$. This compact layer is produced and maintained by fibroblasts in an adjacent layer of loose collagen also derived from the mesoderm, known as the fibroblast layer [35, 37]. The human amnion is almost completely avascular, sourcing nutrients, and exchanging wastes with the amniotic fluid $[34,38]$.

The amnion is separated from the outer chorionic membrane by a space known as the intermediate or spongy layer (shown in Fig. 1) [34, 37]. This space is liquid filled until 12-15 weeks' gestation when the expanding amnion adheres to the chorion. The loose collagen adhesions and hydrated proteoglycans within the intermediate layer allow the amnion to slide independently over the chorion which increases the membrane's tensile strength $[33,35,36]$. 


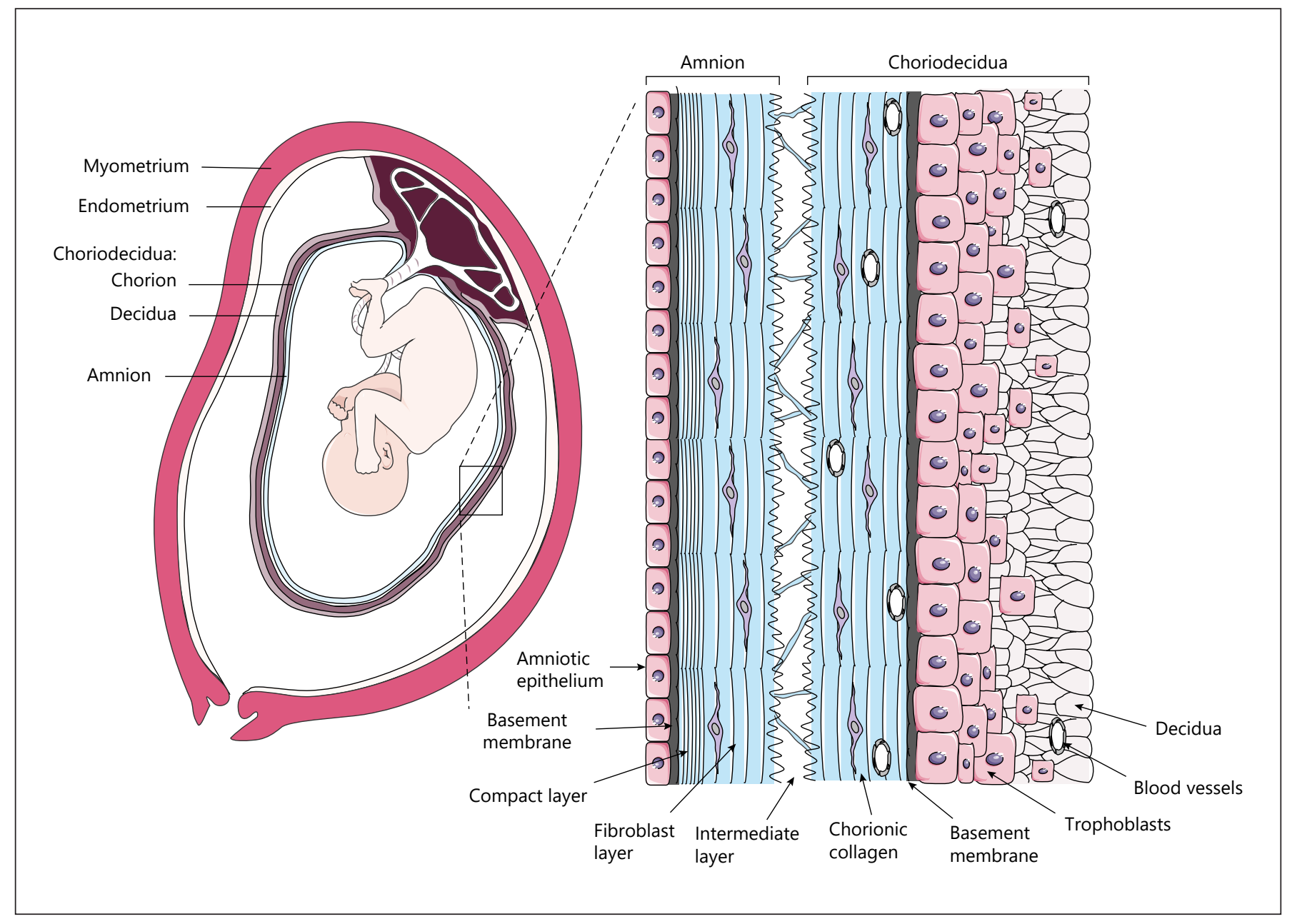

Fig. 1. The arrangement and structure of the human fetal membranes. The human fetal membranes comprise the amnion and choriodecidua. The amnion is composed of a single layer of amniotic epithelium, basement membrane, and underlying collagen. The chorionic collagen faces the amnion and sits on a layer of trophoblasts derived from the placenta. The decidua fuses with the outer surface of the chorion to form the choriodecidua.

The chorion surrounds the amnion and is formed by fusion of the mesoderm with the outer cells of the embryo known as the trophoblasts [34]. The chorionic mesoderm differentiates to become a layer of loose reticular collagen and fibroblasts that face the amnion (shown in Fig. 1) [34]. This collagen is supplied by a network of fetal blood vessels arising from the allantois and its outer surface is lined by the trophoblasts. The outer surface of the chorion is covered by a layer of maternal cells known as the decidua that were once the endometrium overlying the implanted embryo. The decidua is rich with maternal blood vessels and immune cells and fuses with the chorion during early gestation forming the choriodecidua [34].

Why Do the Fetal Membranes Rupture Early after Fetoscopy?

\section{Rupture of the Fetal Membranes at Term}

During pregnancy, there is little change in the composition of the fetal membranes; however, from 37 to 38 weeks gestation, the membranes overlying the cervix become thin and weaken [39-42]. This localized weakening makes the amnion and chorion more susceptible to rupture as the descending fetus and contracting uterus progressively stretch the membranes [37]. The final failing of the membranes plays an important role in promoting the onset of labor and is characterized by membrane separation (chorioamniotic separation) which then promotes rupture of the choriodecidua and amnion in turn (shown in Fig. 2) [33].

Fetal Diagn Ther 2021;48:493-503 
Fig. 2. Fetal membrane weakening and rupture. The amnion and choriodecidua progressively weaken before they rupture both at term and preterm. The final failing of the membranes occurs in 3 phases: (1). the amnion and chorion separate which decreases the tensile strength of the membrane, (2) the decidua and chorion rupture causing the amnion to stretch, and (3) the amnion ruptures [33].
Mid gestation amnion and choriodecidua:

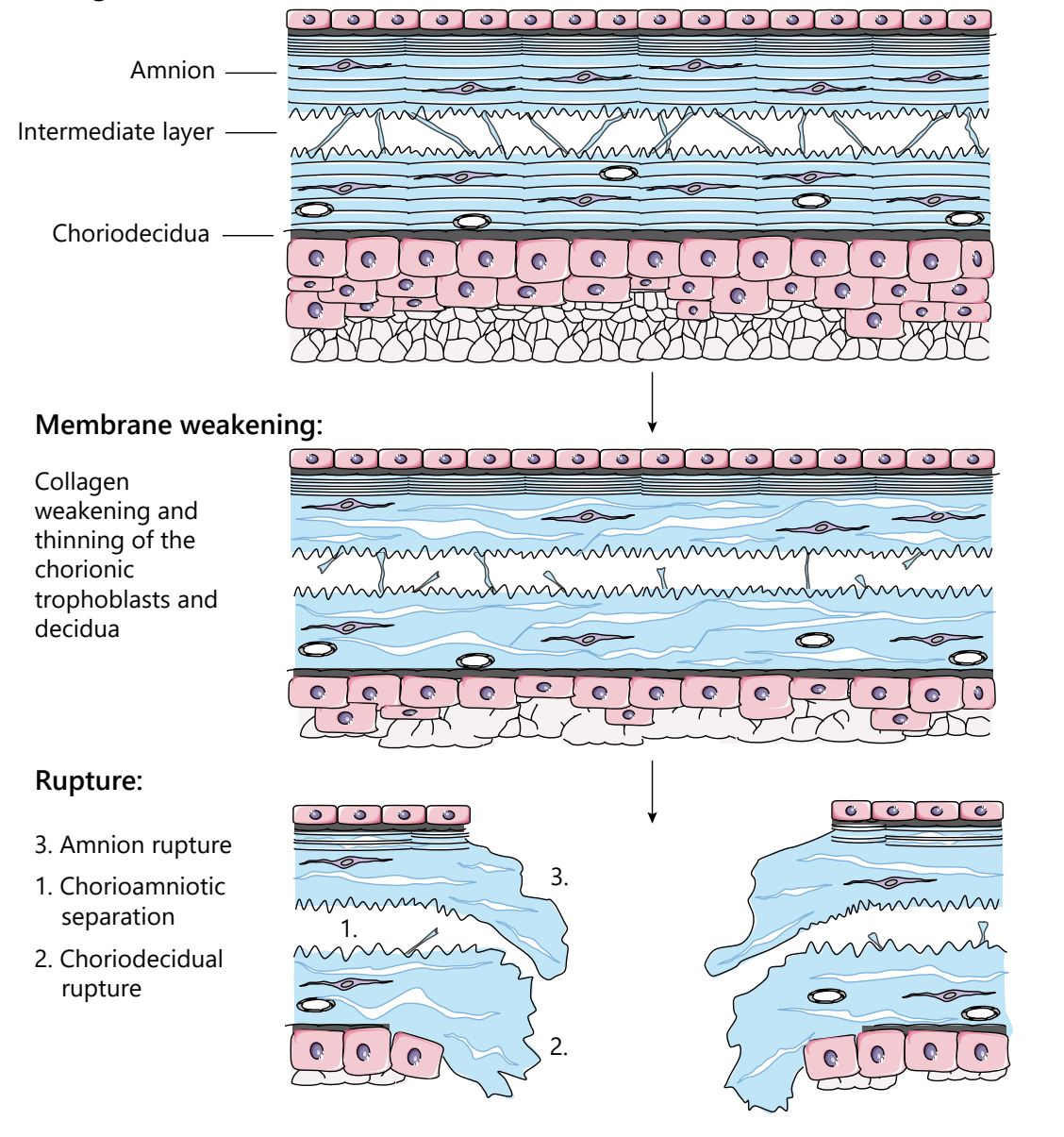

The progressive membrane weakening that precedes term rupture is thought to be mediated by a family of collagen degrading enzymes known as matrix metalloproteases (MMPs) and their endogenous tissue inhibitors (TIMPs) [43-45]. During late gestation, amniotic epithelial cells and chorionic trophoblasts increase the proportion of activated MMPs, particularly MMP-9, within the membrane while reducing TIMPs [45]. Increased MMP activity causes disruption and degradation of structural membrane collagens which reduces the membrane's tensile strength [39, 42, 46-54]. These changes overlying the cervix have been described as the "zone of altered morphology" and can be distinguished histologically in human explants as the swelling of membrane collagen and thinning of the chorionic trophoblasts and decidua [36, 47]. Similar changes in fetal membrane collagen have been documented in animal models preceding labor [36, $39,55-57]$.
There have been significant efforts to understand the factors that normally induce MMP-associated weakening of the late gestation fetal membranes. Although a common pathway is yet to be identified, various genetic (apoptosis of the amniotic epithelium and chorionic trophoblasts [49, 55, 58-65]), epigenetic (changes in MMP and TIMP promotor genes [66, 67]), physical (increasing membrane stretch $[39,68-70]$ ), inflammatory (cytokines release by local immune cells and accumulating oxidative stress [39, 71, 72]), and hormonal (increased relaxin levels $[6,73])$ factors have been suggested.

\section{Possible Mechanisms of latrogenic PPROM}

While spontaneous PPROM is a complex and multifactorial pathology, many known risk factors damage the fetal membranes and prematurely upregulate membrane 
weakening and rupture $[37,74]$. Puncturing the membranes with the fetoscopic port, distending the uterus with unconditioned $\mathrm{CO}_{2}$, and diluting the residual amniotic fluid during fetoscopy may all damage the fetal membranes intraoperatively and increase the risk of iPPROM.

\section{Postoperative Chorioamniotic Separation}

Chorioamniotic separation is identified on ultrasound after $20-40 \%$ of fetoscopic procedures and significantly increases the risk iPPROM [4, 9, 27, 75-77]. This separation is thought to result from friction between the fetoscopic port and fetal membranes which damages the loose collagen adhesions holding the membranes together $[76,78]$. As described above, chorioamniotic separation plays an important biomechanical role in promoting term fetal membrane rupture and similar membrane weakening after fetoscopy may predispose iPPROM [33].

\section{Membrane Apoptosis or Damage at the Port Site}

In addition to causing chorioamniotic separation, the fetoscopic ports may damage the cells surrounding the insertion point. Histological studies have identified apoptosis in the amniotic epithelium and chorionic trophoblasts surrounding the port sites as well as disorganization of the membrane collagen [78]. This injury is thought to be due to shearing forces between the fetoscopic port and fetal membranes as the port is inserted or the instruments are manipulated during surgery [3]. Although apoptosis is an important trigger of MMPs, the effect of this injury on the risk of iPPROM after fetoscopy remains unclear $[29,49,55,58-65]$.

\section{Membrane Overdistension}

While the fetal membranes tolerate the progressive stretch caused by the growing fetus and excessive stretch, such as in multi-gestation pregnancies or polyhydramnios, trigger membrane weakening increases the risk of spontaneous PPROM [37]. Liquid or gaseous distension of the fetal membranes during fetoscopy may trigger similar weakening mechanisms after surgery and increase the risk of iPPROM. Human case series reporting mean amniotic insufflation pressures of $\approx 15 \mathrm{~mm} \mathrm{Hg}$ report higher iPPROM rates than centers using $\approx 12 \mathrm{~mm} \mathrm{Hg}[5,8,9,27]$. While this difference may represent increased membrane injury and weaken with increased distension during fetoscopy, differences in surgical protocol between these cohorts, such as the use of fetal membrane sutures and heated, humidified $\mathrm{CO}_{2}$ for insufflation could also explain the differences in iPPROM rates [27].

Why Do the Fetal Membranes Rupture Early after Fetoscopy?

\section{Membrane Dehydration and Desiccation}

The amniotic fluid plays an important role in hydrating amniotic collagen and maintains the membrane's tensile strength [79]. Prolonged amnion exposure to gas in vitro dehydrates amniotic collagen making it brittle and more likely to rupture $[79,80]$. While this weakening is reversible in vitro when the amnion is reexposed to liquid, similar dehydration and weakening may occur during amniotic insufflation, increasing the likelihood of iPPROM after fetoscopy [79].

In addition to dehydrating amniotic collagen, the low temperature $\left(\approx 22^{\circ} \mathrm{C}\right)$ and humidity $(0-5 \%)$ of insufflated $\mathrm{CO}_{2}$ may damage the amniotic epithelium, upregulate MMPs, and increase the risk of iPPROM [81]. Preliminary sheep studies have shown that amniotic insufflation with unmodified (cold and dry) $\mathrm{CO}_{2}$ increases membrane inflammatory cell counts which may represent a response to amnion damage [30, 31]. Other fields of endoscopy have demonstrated peritoneal and pleural desiccation following exposure to cold, dry $\mathrm{CO}_{2}$ insufflation [80,82-85]. While the peritoneum, pleura, and amniotic epithelium are anatomically different, they are all liquid-lined epithelium and appear to be susceptible to injury when exposed to $\mathrm{CO}_{2}$ for prolonged periods.

\section{Diluting the Amniotic Fluid}

The amniotic fluid is often replaced with warmed Ringer's lactate either during fetoscopy or following amniotic insufflation [27, 78]. As Ringer's lactate has lower osmolarity than normal amniotic fluid, surgeons rely on fetal secretions (urine, lung, nasal, and salivary) and intramembranous reabsorption to normalize the amniotic fluid osmolarity after surgery $[38,78,79,86,87]$. The complete replacement of the amniotic fluid, after fetoscopy, is expected to take up to 48 hours [38]. Both in vitro and in vivo studies have shown that short-term membrane exposure to low osmolarity solutions induces apoptosis in the amniotic epithelium and may directly weaken amniotic collagen $[78,79,86]$. These changes are likely due to the rapid movement of water from the dilute amniotic fluid into amniotic epithelial cells and between the collagen fibrils. Apoptosis of the amniotic epithelium increases MMP activity which, in combination with weakened collagen, may increase the risk of iPPROM after fetoscopy $[65,79,80]$. 


\section{Preventing latrogenic PPROM}

Efforts to prevent iPPROM after fetoscopy have mainly focused on minimizing membrane damage around the fetoscopic port and preventing chorioamniotic separation. However, more recently, emphasis has been placed on protecting the amniotic epithelium during fetoscopy by heating and humidifying the insufflated $\mathrm{CO}_{2}$.

\section{Alternative Port Insertion Techniques}

The Seldinger technique was adopted from vascular procedures as a way of minimizing local membrane trauma and preventing chorioamniotic separation during fetoscopic port insertion $[3,21,88,89]$. Instead of directly puncturing the membranes with a large diameter trocar, the port hole is created sequentially using a thin needle, guidewire, and conical dilator. While the Seldinger technique has been shown to reduce postoperative amniorrhexis in small human case series, larger cohort studies have not yet identified any reduction in iPPROM rates $[3,21,26]$.

An oblique puncture technique has also been attempted to offset the holes left in the membranes after surgery and prevent chorioamniotic separation. While this technique has shown some success in vitro, it has not been adopted routinely into human fetoscopy [90]. More recently, surgeons have sutured the fetal membranes to the uterine wall during the port insertion to prevent chorioamniotic separation [27]. A similar membrane plication technique has shown success in rabbits [14]. While this technique was associated with lower iPPROM rates in small case series compared to similar procedures, larger cohort studies are still required to confirm this potential benefit $[4,27]$.

\section{Reducing the Diameter of Fetoscopic Instruments}

One large retrospective study identified that the maximum instrument diameter employed during fetoscopy significantly predicted iPPROM [11]. Although this suggests that reducing port diameters could reduce the risk of iPPROM, similar retrospective studies have not identified this association nor a clinical benefit reducing port diameters (i.e., from 10 to 8 French) [3,26]. Other studies have suggested that factors increasing membrane friction at the port site such as longer surgical durations, more complex procedures, an anterior placenta, and inserting instruments without a port may have a greater impact on the risk of iPPROM than the size of the holes left in the membranes $[3,6,11]$.

In addition to reducing the port diameter, there have also been considerable efforts to reduce the number of ports employed during fetoscopy [27]. While procedures using 2 or 3 ports generally report higher iPPROM rates than single-port procedures, surgical and pathology-specific factors make it difficult to isolate the effect of port number on the risk of iPPROM [11].

\section{Fetal Membrane Plugs, Glues, and Patches}

A variety of fetal membrane plugs [6, 12-19], tissue sealants [14, 17, 28, 91-97], adhesive patches [17, 23-25], and membrane welding techniques [98] have been developed in preclinical models to seal punctured or ruptured fetal membranes (summarized in Table 1). Collagen/gelatin plugs are one of the few techniques trialed in humans during fetoscopy; however, there is limited evidence to suggest they reduce the iPPROM compared to leaving the membranes unsealed [20-22]. Despite this limited success, new minimally invasive techniques to apply membrane sealing therapies continue to be developed and show promise in vitro [99].

\section{Heated and Humidified Amniotic Insufflation}

Sheep studies have shown that heating and humidifying the $\mathrm{CO}_{2}$ used for amniotic insufflation reduce inflammatory cell counts in the membranes compared to cold and dry $\mathrm{CO}_{2}$ [30]. Several fetoscopic centers have recently adopted heated and humidified amniotic insufflation and reported notably lower rates of iPPROM in small case series [4, 27, 29]. Histological studies have also shown similar levels of membrane injury between membranes exposed to heated, humidified $\mathrm{CO}_{2}$, and noninsufflated controls [29]. However, like many of the factors discussed above, the small number of published cases and variability in surgical technique between centers make it difficult isolating the impact of heated and humidified $\mathrm{CO}_{2}$ on reducing the risk of iPPROM.

\section{Preclinical Models of iPPROM}

Given the vulnerability of human fetuses undergoing fetoscopy, it is essential that studies investigating the mechanisms of iPPROM and developing new therapies are performed in preclinical models. Human fetal membrane explants, rodents, rabbits, sheep, pigs, and nonhuman primates are the most accessible models and have been used extensively for pregnancy-related research (summarized in Table 2) [100]. However, there is considerable variability in the fetal membrane structure and rupture physiology among these models that researchers should be aware of when aiming to translate their findings to human fetoscopy. 
Table 2. Comparative anatomy and physiology of the fetal membranes in humans and domestic species

\begin{tabular}{|c|c|c|c|c|c|c|}
\hline & Human & Rodent & Rabbit & Sheep & Pigs & $\begin{array}{l}\text { Non-human } \\
\text { primates }\end{array}$ \\
\hline \multicolumn{7}{|l|}{ Placental and fetal membrane anatomy } \\
\hline Amnion & Present & Present & Present & Present & Present & Present \\
\hline Chorion & $\begin{array}{l}\text { Fused with } \\
\text { decidua }\end{array}$ & $\begin{array}{l}\text { Fused with } \\
\text { decidua }\end{array}$ & $\begin{array}{l}\text { Fused with } \\
\text { decidua }\end{array}$ & $\begin{array}{l}\text { Fused with } \\
\text { decidua }\end{array}$ & $\begin{array}{l}\text { Fused with } \\
\text { decidua }\end{array}$ & $\begin{array}{l}\text { Fused with } \\
\text { decidua }\end{array}$ \\
\hline Average gestational age, days & 266 & $20-22$ & 30 & 147 & 115 & 168 \\
\hline Number of fetuses & 1 & $5-9$ & 5 & $1-2$ & $10-14$ & $1-2$ \\
\hline Condition of gestational sac at delivery & $\begin{array}{l}\text { Partially intact } \\
\text { or ruptured }\end{array}$ & Ruptured & $\begin{array}{l}\text { Intact or } \\
\text { ruptured }\end{array}$ & $\begin{array}{l}\text { Intact or } \\
\text { partially intact }\end{array}$ & Ruptured & Ruptured \\
\hline Naturally occurring PPROM & Yes & No & No & No & No & No \\
\hline Spontaneous membrane healing & No & Yes & Yes & No & Yes & No \\
\hline
\end{tabular}

\section{Spontaneous Membrane Rupture}

Unlike pregnancy complications, such as fetal growth restriction, researchers are yet to develop a preclinical model of iPPROM. This is likely because spontaneous PPROM does not appear to occur naturally in other species $[34,40]$. Until recently, this has been attributed to the human's evolution of an upright posture that places unique downward forces on the cervical fetal membranes during pregnancy [40]. However, biomechanical studies have also shown that the human fetal membranes are considerably weaker, and rupture more readily than those of many domestic species, including sheep and pigs [40]. These biomechanical differences mean that only human fetal membrane explants may accurately combine cellular markers of weakening or damage with biomechanical changes that predispose rupture. However, human explants can only be collected after delivery and the composition of these tissues may not be representative of midgestation fetal membranes undergoing fetoscopy [34, 101]. This highlights the need to understand the limitations of available animal models in fetal membrane research.

Despite biomechanical differences, the inflammatory responses to injury and membrane weakening cascades involving MMPs are consistent among humans and most domestic species $[18,36,39,55-57]$. This suggests that preclinical animal studies investigating iPPROM and potential therapies should focus on the biology of membrane injury and weakening rather than changes in mechanical rupture properties $[74,102]$.

\section{Fetal Membrane Structure and Integrity}

There are also anatomical differences between human fetal membranes and those of domestic species. Many mammals have an additional allantoic membrane present at term (summarized in Table 2) [34, 101]. Embryologically, the allantois is an outpouching of the primordial urinary bladder that expands beside the amnion and fuses with the chorion forming the chorioallantois. The allantois is temporary in humans and absent by the time fetal surgery is performed at mid-gestation [34, 101]. However, in sheep and pigs, it persists throughout pregnancy as a large sac filled with fetal urine. A relatively smaller allantois is also seen throughout pregnancy in rabbits $[34,101]$. Researchers should be aware of this difference so that interventions, therapies, and tissue collection in preclinical animal studies of iPPROM are performed on combined sections of chorioamnion that are representative of human fetal membranes. The allantois is easily distinguished from the amnion by the presence of clear, dark fetal urine within the allantoic sac compared to the lighter, cloudy amniotic fluid that contains a mixture of urine, mucous, lung liquid, and skin cells [38].

The fetal membranes of many domestic species also contain considerably more blood vessels than human fetal membranes. Membrane vasculature is largely dependent on the anatomical arrangement of the placenta [103, 104]. Primates (including humans), rabbits, and rodents have a discoid placenta that embeds on one side of the uterus (summarized in Table 2) [104]. The small number of blood vessels within the chorion arises from the allantois and drains into the fetal sinus venosus. The placenta of sheep is comprised of multiple smaller placental struc- 
tures (cotyledons) randomly distributed within the uterus [104]. Cotyledons are interconnected by a large network of fetal blood vessels running within the chorion, which significantly increases membrane vasculature relative to humans [103]. Increased vasculature is also seen in the fetal membranes of pigs and guinea pigs where the placenta occupies the entire internal surface of the uterus (a diffuse arrangement) [104]. Where possible, preclinical studies investigating mechanisms of iPPROM or aiming to seal membrane defects should use regions away from dense patches of vasculature.

\section{Spontaneous Healing}

Unlike humans, the fetal membranes of rodents, rabbits, and pigs show some ability to heal after being punctured at mid-gestation (summarized in Table 2) $[6,12,16$, $18,25,105]$. In rodent and rabbit membranes, the amniotic epithelium and fibroblasts proliferate around the puncture site and are able to close small defects $(<1 \mathrm{~cm})$ within $48-72$ hours $[6,12,16,18,105]$. Larger defects either heal over longer periods or incompletely $[6,105]$. Spontaneous membrane healing in these animal models may exaggerate the efficacy of new techniques aiming to prevent iPPROM in humans.

The fetal membranes of sheep and rhesus monkeys have shown limited healing capacity like humans and may therefore be more appropriate models to test techniques aiming to prevent membrane injury [18]. Sheep also have considerably longer gestations than other animal models and their large size permits invasive monitoring of fetal physiology during pregnancy [100]. These advantages are particularly important as membrane closure techniques should demonstrate efficacy sealing the membranes for several weeks or months and be safe for the fetus when in contact with the amniotic fluid.

\section{Conclusions}

The etiology of iPPROM after fetoscopy is not entirely understood; however, appears multifactorial. Puncturing the membranes with the fetoscopic port, distending the uterus with unconditioned $\mathrm{CO}_{2}$, and diluting the residual amniotic fluid during fetoscopy potentially weakens the membranes prematurely and increases the risk of iPPROM. Despite multiple attempts to develop novel preventions in preclinical models, iPPROM remains a major concern that limits the benefits of fetoscopy. It is important to consider that the structure and integrity of human fetal membranes are unique and thus promising results from preclinical studies will not always translate into clinical improvements. However, careful combination of large animal studies and human membrane explants may shed light on new ways to reduce iPPROM in the future.

\section{Conflict of Interest Statement}

The authors have no conflicts of interest to declare.

\section{Funding Sources}

This research was supported by an Australian Government Research Training Program Scholarship awarded to Benjamin Amberg at Monash University with Award number 25129015.

\section{Author Contributions}

B.J.A., R.J.H., K.A.R., K.J.C., S.B.H., and P.L.J.D. contributed to the conception and planning of this review. B.J.A. and P.L.J.K. prepared the original manuscript which was then reviewed and approved by R.J.H., K.A.R., K.J.C., and S.B.H. prior to submission.

\section{References}

1 Graves CE, Harrison MR, Padilla BE. Minimally invasive fetal surgery. Clin Perinatol. 2017 Dec;44(4):729-51.

2 Moise KJ Jr, Tsao K, Papanna RM, Bebbington MW. Fetoscopic repair of meningomyelocele. Obstet Gynecol. 2015 Sep;126(3):674.

3 Petersen SG, Gibbons KS, Luks FI, Lewi L, Diemert A, Hecher K, et al. The impact of entry technique and access diameter on prelabour rupture of membranes following primary fetoscopic laser treatment for Twin-Twin Transfusion syndrome. Fetal Diagn Ther. 2016;40(2):100-9.
4 Sanz Cortes M, Lapa DA, Acacio GL, Belfort M, Carreras E, Maiz N, et al. Proceedings of the first annual meeting of the international fetoscopic myelomeningocele repair consortium. Ultrasound Obstet Gynecol. 2019 Jun 1; 53(6):855-63.

5 Kohl T. Percutaneous minimally invasive fetoscopic surgery for spina bifida aperta. Part I: surgical technique and perioperative outcome. Ultrasound Obstet Gynecol. 2014 Nov; 44(5):515-24.
6 Devlieger R, Millar LK, Bryant-Greenwood G, Lewi L, Deprest JA. Fetal membrane healing after spontaneous and iatrogenic membrane rupture: a review of current evidence. Am J Obstet Gynecol. 2006;195(6):1512-20.

7 Harrison MR. Surgically correctable fetal disease. Am J Surg. 2000 Nov;180(5):335-42.

8 Lapa Pedreira DA, Acacio GL, Goncalves RT, Sa RAM, Brandt RA, Chmait R, et al. Percutaneous fetoscopic closure of large open spina bifida using a bilaminar skin substitute. Ultrasound Obstet Gynecol. 2018 Oct;52(4):45866. 
9 Pedreira DA, Zanon N, Nishikuni K, Moreira de Sá RA, Acacio GL, Chmait RH, et al. Endoscopic surgery for the antenatal treatment of myelomeningocele: the CECAM trial. Am J Obstet Gynecol. 2016 Jan;214(1):111-e11.

10 Stirnemann J, Djaafri F, Kim A, Mediouni I, Bussieres L, Spaggiari E, et al. Preterm premature rupture of membranes is a collateral effect of improvement in perinatal outcomes following fetoscopic coagulation of chorionic vessels for twin-twin transfusion syndrome: a retrospective observational study of 1,092 cases. BJOG. 2018 Aug 1;125(9):1154-62.

11 Beck V, Lewi P, Gucciardo L, Devlieger R. Preterm prelabor rupture of membranes and fetal survival after minimally invasive fetal surgery: a systematic review of the literature. Fetal Diagn Ther. 2012;31(1):1-9.

12 Deprest JA, Papadopulos NA, Decaluw H, Yamamoto H, Lerut TE, Gratacós E. Closure techniques for fetoscopic access sites in the rabbit at mid-gestation. Hum Reprod. 1999 Jul;14(7):1730-4.

13 Liekens D, Lewi L, Jani J, Heyns L, Poliard E, Verbist G, et al. Enrichment of collagen plugs with platelets and amniotic fluid cells increases cell proliferation in sealed iatrogenic membrane defects in the foetal rabbit model. Prenat Diagn. 2008 Jun 1;28(6):503-7.

14 Papadopulos NA, Van Ballaer PP, Ordoñez JL, Laermans IJ, Vandenberghe K, Lerut TE, et al. Fetal membrane closure techniques after hysteroamniotomy in the midgestational rabbit model. Am J Obstet Gynecol. 1998 May 1; 178(5):938-42.

15 Mallik AS, Fichter MA, Rieder S, Bilic G, Stergioula S, Henke J, et al. Fetoscopic closure of punctured fetal membranes with acellular human amnion plugs in a rabbit model. Obstet Gynecol. 2007 Nov;110(5):1121-9.

16 Gratacós E, Wu J, Yesildaglar N, Devlieger R, Pijnenborg R, Deprest JA. Successful sealing of fetoscopic access sites with collagen plugs in the rabbit model. Am J Obstet Gynecol. 2000;182(1):142-6.

17 Devlieger R, Ardon H, Verbist L, Gratacós E, Pijnenborg R, Deprest JA. Increased polymorphonuclear infiltration and iatrogenic amniotic band after closure of fetoscopic access sites with a bioactive membrane in the rabbit at midgestation. Am J Obstet Gynecol. 2003;188(3):844-8.

18 Devlieger R, Riley SC, Verbist L, Leask R, Pijnenborg R, Deprest JA. Matrix metalloproteinases- 2 and -9 and their endogenous tissue inhibitors in tissue remodeling after sealing of the fetal membranes in a sheep model of fetoscopic surgery. J Soc Gynecol Investig. 2002 May 1;9(3):137-45.

19 Luks FI, Deprest JA, Peers KH, Steegers EA, van der Wildt B. Gelatin sponge plug to seal fetoscopy port sites: technique in ovine and primate models. Am J Obstet Gynecol. 1999 Oct 1;181(4):995-6.

20 Papanna R, Molina S, Moise KY, Moise KJ Jr, Johnson A. Chorioamnion plugging and the risk of preterm premature rupture of mem- branes after laser surgery in twin-twin transfusion syndrome. Ultrasound Obstet Gynecol. 2010 Mar;35(3):337-43.

21 Chang J, Tracy TF Jr, Carr SR, Sorrells DL Jr, Luks FI. Port insertion and removal techniques to minimize premature rupture of the membranes in endoscopic fetal surgery. J Pediatr Surg. 2006 May;41(5):905-9.

22 Engels AC, Van Calster B, Richter J, DeKoninck P, Lewi L, De Catte L, et al. Collagen plug sealing of iatrogenic fetal membrane defects after fetoscopic surgery for congenital diaphragmatic hernia. Ultrasound Obstet Gynecol. 2014 Jan;43(1):54-9.

23 Mann LK, Papanna R, Moise KJ, Byrd RH, Popek EJ, Kaur S, et al. Fetal membrane patch and biomimetic adhesive coacervates as a sealant for fetoscopic defects. Acta Biomater. 2012 Jul 1;8(6):2160-5

24 Micheletti T, Eixarch E, Berdun S, Febas G, Mazza E, Borrós S, et al. Ex-vivo mechanical sealing properties and toxicity of a bioadhesive patch as sealing system for fetal membrane iatrogenic defects. Sci Rep. 2020 Oct 29; 10(1):18608.

25 Papanna R, Mann LK, Tseng SC, Stewart RJ, Kaur SS, Swindle MM, et al. Cryopreserved human amniotic membrane and a bioinspired underwater adhesive to seal and promote healing of iatrogenic fetal membrane defect sites. Placenta. 2015 Aug 1;36(8):888-94.

26 Petersen S, Done E, Gardener G, Lewi L, Van Schoubroeck D, Devlieger R, et al. OP09.08: rate of amniorrhexis is not affected by fetoscopic access cannula diameter. Ultrasound Obstet Gynecol. 2009;34(S1):90-1.

27 Belfort MA, Whitehead WE, Shamshirsaz AA, Bateni ZH, Olutoye OO, Olutoye OA, et al. Fetoscopic open neural tube defect repair: development and refinement of a two-port, carbon dioxide insufflation technique. Obstet Gynecol. 2017 Apr;129(4):734-43.

28 Kivelio A, Dekoninck P, Perrini M, Brubaker CE, Messersmith PB, Mazza E, et al. Mussel mimetic tissue adhesive for fetal membrane repair: initial in vivo investigation in rabbits. Eur J Obstet Gynecol Reprod Biol. 2013 Dec 1;171(2):240-5

29 Sanz Cortes M, Castro E, Sharhan D, Torres P, Yepez M, Espinoza J, et al. Amniotic membrane and placental histopathological findings after open and fetoscopic prenatal neural tube defect repair. Prenat Diagn. 2019 Mar; 39(4):269-79.

30 Amberg BJ, Hodges RJ, Kashyap AJ, Skinner SM, Rodgers KA, McGillick EV, et al. Physiological effects of partial amniotic carbon dioxide insufflation with cold, dry vs heated, humidified gas in a sheep model. Ultrasound Obstet Gynecol. 2019 Mar;53(3):340-7.

31 Skinner S, Crossley K, Amberg B, Kashyap A, Hooper S, Deprest JA, et al. The effects of partial amniotic carbon dioxide insufflation in an ovine model. Prenat Diagn. 2018 Dec;38(13): 994-1003.

32 Papanna R, Mann LK, Moise KY, Johnson A, Moise KJ Jr. Absorbable gelatin plug does not prevent iatrogenic preterm premature rupture of membranes after fetoscopic laser surgery for twin-twin transfusion syndrome. Ultrasound Obstet Gynecol. 2013 Oct;42(4): 456-60.

33 Arikat S, Novince RW, Mercer BM, Kumar D, Fox JM, Mansour JM, et al. Separation of amnion from choriodecidua is an integral event to the rupture of normal term fetal membranes and constitutes a significant component of the work required. Am J Obstet Gynecol. 2006 Jan; 194(1):211-7.

34 Carter AM. IFPA senior award lecture: mammalian fetal membranes. Placenta. 2016 Dec 1;48(Suppl 1):S21-30.

35 Malak TM, Ockleford CD, Bell SC, Dalgleish R, Bright N, Macvicar J. Confocal immunofluorescence localization of collagen types I, III, IV, V and VI and their ultrastructural organization in term human fetal membranes. Placenta. 1993 Jul-Aug;14(4):385-406.

36 Strauss JF 3rd. Extracellular matrix dynamics and fetal membrane rupture. Reprod Sci. 2013;20(2):140-53

37 Parry S, Strauss JF. Premature rupture of the fetal membranes. N Engl J Med. 1998 Mar 5; 338(10):663-70.

38 Brace RA, Cheung CY. Regulation of amniotic fluid volume: evolving concepts. Adv Exp Med Biol. 2014;814:49-68.

39 Kumar D, Moore RM, Mercer BM, Mansour JM, Redline RW, Moore JJ. The physiology of fetal membrane weakening and rupture: Insights gained from the determination of physical properties revisited. Placenta. 2016 Jun; 42:59-73.

40 Borazjani A, Weed BC, Patnaik SS, Feugang JM, Christiansen D, Elder SH, et al. A comparative biomechanical analysis of term fetal membranes in human and domestic species. Am J Obstet Gynecol. 2011 Apr;204(4):365-36.

41 Joyce EM, Moore JJ, Sacks MS. Biomechanics of the fetal membrane prior to mechanical failure: review and implications. Eur J Obstet Gynecol Reprod Biol. 2009;144(Suppl 1):S121-7.

42 Rangaswamy N, Abdelrahim A, Moore RM, Uyen L, Mercer BM, Mansour JM, et al. Biomechanical characteristics of human fetal membranes. Preterm fetal membranes are stronger than term fetal membranes. Gynecol Obstet Fertil. 2011 Jun;39(6):373-7.

43 Vettraino IM, Roby J, Tolley T, Parks WC. Collagenase-I, stromelysin-I, and matrilysin are expressed within the placenta during multiple stages of human pregnancy. Placenta. 1996 Nov; $17(8): 557-63$.

44 Vadillo-Ortega F, González-Avila G, Furth EE, Lei H, Muschel RJ, Stetler-Stevenson WG, et al. 92-kd type IV collagenase (matrix metalloproteinase-9) activity in human amniochorion increases with labor. Am J Pathol. 1995. 146(1):148-56

45 Fortunato SJ, Menon R, Lombardi SJ. Collagenolytic enzymes (gelatinases) and their inhibitors in human amniochorionic membrane. Am J Obstet Gynecol. 1997 Oct;177(4): 731-41.
Why Do the Fetal Membranes Rupture Early after Fetoscopy?
Fetal Diagn Ther 2021;48:493-503 DOI: $10.1159 / 000517151$ 
46 Moore RM, Mansour JM, Redline RW, Mercer BM, Moore JJ. The physiology of fetal membrane rupture: insight gained from the determination of physical properties. Placenta. 2006 Nov-Dec 11;27(11-12):1037-51.

47 McLaren J, Malak TM, Bell SC. Structural characteristics of term human fetal membranes prior to labour: identification of an area of altered morphology overlying the cervix. Hum Reprod. 1999 Jan;14(1):23741.

48 McParland PC, Taylor DJ, Bell SC. Mapping of zones of altered morphology and chorionic connective tissue cellular phenotype in human fetal membranes (amniochorion and decidua) overlying the lower uterine pole and cervix before labor at term. Am J Obstet Gynecol. 2003 Nov;189(5):1481-8.

49 McLaren J, Taylor DJ, Bell SC. Increased incidence of apoptosis in non-labour-affected cytotrophoblast cells in term fetal membranes overlying the cervix. Hum Reprod. 1999 Nov; 14(11):2895-900

50 McLaren J, Taylor DJ, Bell SC. Increased concentration of pro-matrix metalloproteinase 9 in term fetal membranes overlying the cervix before labor: Implications for membrane remodeling and rupture. Am J Obstet Gynecol. 2000 Feb 1;182(2):409-16.

51 Fortner KB, Grotegut CA, Ransom CE, Bentley RC, Feng L, Lan L, et al. Bacteria localization and chorion thinning among preterm premature rupture of membranes. PLoS One. 2014;9(1):e83338.

52 El Khwad M, Stetzer B, Moore RM, Kumar D, Mercer B, Arikat S, et al. Term human fetal membranes have a weak zone overlying the lower uterine pole and cervix before onset of labor. Biol Reprod. 2005 Mar;72(3):720-6.

53 El Khwad M, Pandey V, Stetzer B, Mercer BM, Kumar D, Moore RM, et al. Fetal membranes from term vaginal deliveries have a zone of weakness exhibiting characteristics of apoptosis and remodeling. J Soc Gynecol Investig. 2006 Apr;13(3):191-5.

54 Rangaswamy N, Kumar D, Moore R, Mercer BM, Mansour J, Redline R, et al. Weakening and rupture of human fetal membranes - biochemistry and biomechanics. 2012. p. 32 .

55 Lei H, Furth EE, Kalluri R, Chiou T, Tilly KI, Tilly JL, et al. A program of cell death and extracellular matrix degradation is activated in the amnion before the onset of labor. J Clin Invest. 1996 Nov 1;98(9):1971-8.

56 Lei H, Kalluri R, Furth EE, Baker AH, Strauss JF III. Rat amnion type IV collagen composition and metabolism: implications for membrane breakdown1. Biol Reprod. 1999;60(1): $176-82$.

57 Lei H, Vadillo-Ortega F, Paavola LG, Strauss JF 3rd. 92-kDa gelatinase (matrix metalloproteinase-9) is induced in rat amnion immediately prior to parturition. Biol Reprod. 1995 Aug;53(2):339-44.

58 Hung TH, Hsieh TT, Chen SF, Li MJ, Yeh YL. Autophagy in the human placenta throughout gestation. PLoS One. 2013;8(12):e83475.
59 Athayde N, Edwin SS, Romero R, Gomez R, Maymon E, Pacora P, et al. A role for matrix metalloproteinase- 9 in spontaneous rupture of the fetal membranes. Am J Obstet Gynecol. 1998 Nov;179(5):1248-53.

60 Reti NG, Lappas M, Riley C, Wlodek ME, Permezel M, Walker S, et al. Why do membranes rupture at term? Evidence of increased cellular apoptosis in the supracervical fetal membranes. Am J Obstet Gynecol. 2007 May 1; 196(5):484-10.

61 Kumagai K, Otsuki Y, Ito Y, Shibata MA, Abe $\mathrm{H}$, Ueki M. Apoptosis in the normal human amnion at term, independent of $\mathrm{Bcl}-2$ regulation and onset of labour. Mol Hum Reprod. 2001;7(7):681-9.

62 Sağol S, Sağol O, Ozkal S, Asena U. Role of apoptosis, bcl-2 and bax protein expression in premature rupture of fetal membranes. J Reprod Med. 2002 Oct;47(10):809-15.

63 Kataoka S, Furuta I, Yamada H, Kato EH, Ebina Y, Kishida T, et al. Increased apoptosis of human fetal membranes in rupture of the membranes and chorioamnionitis. Placenta. 2002 Feb 1;23(2):224-31.

64 Arechavaleta-Velasco F, Mayon-Gonzalez J, Gonzalez-Jimenez M, Hernandez-Guerrero C, Vadillo-Ortega F. Association of type II apoptosis and 92-kDa type IV collagenase expression in human amniochorion in prematurely ruptured membranes with tumor necrosis factor receptor-1 expression. J Soc Gynecol Investig. 2002 Mar 1;9(2):60-7.

65 Fortunato SJ, Menon R, Bryant C, Lombardi SJ. Programmed cell death (apoptosis) as a possible pathway to metalloproteinase activation and fetal membrane degradation in premature rupture of membranes. Am J Obstet Gynecol. 2000 Jun;182(6):1468-76.

66 Montenegro D, Romero R, Pineles BL, Tarca AL, Kim YM, Draghici S, et al. Differential expression of microRNAs with progression of gestation and inflammation in the human chorioamniotic membranes. Am J Obstet Gynecol. 2007;197(3):289-6.

67 Wang H, Ogawa M, Wood JR, Bartolomei MS, Sammel MD, Kusanovic JP, et al. Genetic and epigenetic mechanisms combine to control MMP1 expression and its association with preterm premature rupture of membranes. Hum Mol Genet. 2008 Apr 15;17(8):1087-96.

68 Maradny EE, Kanayama N, Halim A, Maehara K, Terao T. Stretching of fetal membranes increases the concentration of interleukin-8 and collagenase activity. Am J Obstet Gynecol. 1996 Mar; 174(3):843-9.

69 Maehara K, Kanayama N, Maradny EE, Uezato T, Fujita M, Terao T. Mechanical stretching induces interleukin-8 gene expression in fetal membranes: a possible role for the initiation of human parturition. Eur J Obstet Gynecol Reprod Biol. 1996 Dec;70(2):191-6.

70 Nemeth E, Millar LK, Bryant-Greenwood G. Fetal membrane distention: II. Differentially expressed genes regulated by acute distention in vitro. Am J Obstet Gynecol. 2000 Jan;182(1 Pt 1):60-7.
71 Kumar D, Moore RM, Nash A, Springel E, Mercer BM, Philipson E, et al. Decidual GMCSF is a critical common intermediate necessary for thrombin and TNF induced in-vitro fetal membrane weakening. Placenta. 2014 Dec;35(12):1049-56.

72 Menon R, Richardson LS. Preterm prelabor rupture of the membranes: a disease of the fetal membranes. Semin Perinatol. 2017;41(7): 409-19.

73 Millar LK, Boesche MH, Yamamoto SY, Killeen J, DeBuque L, Chen R, et al. A relaxinmediated pathway to preterm premature rupture of the fetal membranes that is independent of infection. Am J Obstet Gynecol. 1998 Jul;179(1):126-34

74 Padron JG, Saito Reis CA, Kendal-Wright CE. The role of danger associated molecular patterns in human fetal membrane weakening. Front Physiol. 2020 Jun 17;11(602):602.

75 Ortiz JU, Eixarch E, Peguero A, Lobmaier SM, Bennasar M, Martinez JM, et al. Chorioamniotic membrane separation after fetoscopy in monochorionic twin pregnancy: incidence and impact on perinatal outcome. Ultrasound Obstet Gynecol. 2016 Mar;47(3):345-9.

76 Papanna R, Mann LK, Johnson A, SangiHaghpeykar H, Moise KJ. Chorioamnion separation as a risk for preterm premature rupture of membranes after laser therapy for twin-twin transfusion syndrome. Obstet Gynecol. 2010 Apr;115(4):771-6.

77 Egawa M, Hayashi S, Yang L, Sakamoto N, Sago H. Chorioamniotic membrane separation after fetoscopic laser surgery for twintwin transfusion syndrome. Prenat Diagn. 2013 Jan;33(1):89-94.

78 Papanna R, Mann LK, Moise KJ, Kyriakides T, Johnson A, Garcia E, et al. Histologic changes of the fetal membranes after fetoscopic laser surgery for twin-twin transfusion syndrome. Pediatr Res. 2015 Sep 1;78(3):24755.

79 Bircher K, Merluzzi R, Wahlsten A, Spiess D, Simões-Wüst AP, Ochsenbein-Kölble N, et al. Influence of osmolarity and hydration on the tear resistance of the human amniotic membrane. J Biomech. 2020 Jan 2;98:109419.

80 Bircher K, Ehret AE, Spiess D, Ehrbar M, Simões-Wüst AP, Ochsenbein-Kölble N, et al. On the defect tolerance of fetal membranes. Interf Focus. 2019;9(5):20190010.

81 Sammour T, Kahokehr A, Hill AG. Independent testing of the Fisher \& Paykel Healthcare MR860 laparoscopic humidification system. Minim Invasive Ther Allied Technol. 2010 Aug; 19(4):219-23.

82 Binda MM. Humidification during laparoscopic surgery: overview of the clinical benefits of using humidified gas during laparoscopic surgery. Arch Gynecol Obstet. 2015 Nov;292(5):955-71.

83 Ott DE. Desertification of the peritoneum by thin-film evaporation during laparoscopy. JSLS. 2003 Jul-Sep;7(3):189-95. 
84 Mouton WG, Bessell JR, Pfitzner J, Dymock RB, Brealey J, Maddern GJ. A randomized controlled trial to determine the effects of humidified carbon dioxide insufflation during thoracoscopy. Surg Endosc. 1999 Apr 1;13(4): $382-5$.

85 Mouton WG, Naef M, Bessell JR, Otten KT, Wagner HE, Maddern GJ. A randomized controlled trial to determine the effect of humidified carbon dioxide (CO2) insufflation on postoperative pain following thoracoscopic procedures. Surg Endosc. 2001 Jun 1;15(6): $579-81$.

86 Locatelli A, Andreani M, Ghidini A, Verderio M, Pizzardi A, Vergani P, et al. Amnioinfusion in preterm PROM: effects on amnion and cord histology. J Perinatol. 2008 Feb; 28(2):97-101.

87 Robertson P, Faber JJ, Brace RA, Louey S, Hohimer AR, Davis LE, et al. Responses of amniotic fluid volume and its four major flows to lung liquid diversion and amniotic infusion in the ovine fetus. Reprod Sci. 2009;16(1):88-93.

88 Meriki N, Smoleniec J, Challis D, Welsh AW. Immediate outcome of twin-twin transfusion syndrome following selective laser photocoagulation of communicating vessels at the NSW fetal therapy centre. Aust N Z J Obstet Gynaecol. 2010;50(2):112-9.

89 Deprest JA, Evrard VA, Van Schoubroeck D, Vandenberghe K. Endoscopic cord ligation in selective feticide. Lancet. 1996 Sep;348(9031): $890-1$.

90 Gratacos E, Devlieger R, Decaluwe H, Wu J, Nicolini U, Deprest JA. Is the angle of needle insertion influencing the created defect in human fetal membranes? Evaluation of the agreement between specialists' opinions and ex vivo observations. Am J Obstet Gynecol. 2000 Mar;182(3):646-9.
91 Harmanli OH, Wapner RJ, Lontz JF. Efficacy of fibrin glue for in vitro sealing of human chorioamniotic membranes. J Reprod Med. 1998 Nov;43(11):986-90.

92 Louis-Sylvestre C, Rand JH, Gordon RE, Salafia CM, Berkowitz RL. In vitro studies of the interactions between platelets and amniotic membranes: a potential treatment for preterm premature rupture of the membranes. Am J Obstet Gynecol. 1998 Feb;178(2):28793.

93 Reddy UM, Shah SS, Nemiroff RL, Ballas SK, Hyslop T, Chen J, et al. In vitro sealing of punctured fetal membranes: potential treatment for midtrimester premature rupture of membranes. Am J Obstet Gynecol. 2001 Nov; 185(5):1090-3.

94 Haller CM, Buerzle W, Brubaker CE, Messersmith PB, Mazza E, Ochsenbein-Koelble N, et al. Mussel-mimetic tissue adhesive for fetal membrane repair: a standardized ex vivo evaluation using elastomeric membranes. Prenat Diagn. 2011 Jul;31(7):654-60.

95 Bilic G, Brubaker C, Messersmith PB, Mallik AS, Quinn TM, Haller C, et al. Injectable candidate sealants for fetal membrane repair: bonding and toxicity in vitro. Am J Obstet Gynecol. 2010;202(1):85-9.

96 Ochsenbein-Kölble N, Jani J, Lewi L, Verbist G, Vercruysse L, Portmann-Lanz B, et al. Enhancing sealing of fetal membrane defects using tissue engineered native amniotic scaffolds in the rabbit model. Am J Obstet Gynecol. 2007 Mar;196(3):263-7.

97 Mogami H, Kishore AH, Word RA. Collagen type 1 accelerates healing of ruptured fetal membranes. Sci Rep. 2018 Jan 12;8(1):696.
98 Mendoza GA, Acuña E, Allen M, Arroyo J, Quintero RA. In vitro laser welding of amniotic membranes. Lasers Surg Med. 1999 Jan 1;24(5):315-8.

99 Devaud YR, Züger S, Zimmermann R, Ehrbar M, Ochsenbein-Kölble N. Minimally invasive surgical device for precise application of bioadhesives to prevent iPPROM. Fetal Diagn Ther. 2019;45(2):102-10.

100 Grigsby PL. Animal models to Study placental development and function throughout normal and dysfunctional human pregnancy. Semin Reprod Med. 2016;34(1):11-6.

101 Stempfle G, McGowen MR, Caravas JA, Wildman DE. From PPROM to caul: the evolution of membrane rupture in mammals. Appl Transl Genom. 2013;2:70-7.

102 Regan JK, Kannan PS, Kemp MW, Kramer BW, Newnham JP, Jobe AH, et al. Damageassociated molecular pattern and fetal membrane vascular injury and collagen disorganization in lipopolysaccharide-induced intra-amniotic inflammation in fetal sheep. Reprod Sci. 2016 Jan;23(1):69-80.

103 Brace RA, Gilbert WM, Thornburg KL. Vascularization of the ovine amnion and chorion: a morphometric characterization of the surface area of the intramembranous pathway. Am J Obstet Gynecol. 1992 Dec 1; 167(6):1747-55.

$104 \mathrm{Hafez}$ S. Chapter one: comparative placental anatomy: divergent structures serving a common purpose. In: Huckle WR, editor. Progress in molecular biology and translational science. Academic Press; 2017. p. $1-28$

105 Sopher D. The response of rat fetal membranes to injury. Ann R Coll Surg Engl. 1972; 51(4):240-9.
Why Do the Fetal Membranes Rupture Early after Fetoscopy?
Fetal Diagn Ther 2021;48:493-503

DOI: $10.1159 / 000517151$ 